\title{
Medical History Subcategory
}

National Cancer Institute

\section{Source}

National Cancer Institute. Medical History Subcategory. NCI Thesaurus. Code C83143.

A sub-division of the medical history classification. 